\title{
Teacher's Illocutionary Acts in Online Learning Interactions
}

\author{
Sukinah $^{1 *}$, Anwar Efendi ${ }^{2}$ (iD) \\ 1,2 Indonesian Language Education and Literature Graduate Program, Universitas Negeri Yogyakarta, Indonesia \\ *Corresponding author: sukinah.zulfa@yahoo.co.id
}

\begin{abstract}
Speech acts happen within the communication between teachers and students in online learning interactions. This study aims to describe the forms of illocutionary acts and representations of an Indonesian teacher's power strategies in online learning interactions through WhatsApp and Google Classroom. A descriptive qualitative was used to garner written conversations between the teacher and the students. This study involves an Indonesian language teacher and students, totaling 36 students. The data was gathered from written conversational speeches conveyed by the teacher and students through WhatsApp and Google Classroom during online learning. The data was analyzed using Miles and Huberman's model, including data collection, data reduction (data presentation), drawing temporary conclusion and verification, and conclusion and recommendation. The study reveals several types of illocutionary acts, such as assertive, directive, expressive and commissive - while no types of illocutionary acts are found. The teacher's representation of the power strategy in online learning interactions includes speech control, threatening, and being angry with insinuation.
\end{abstract}

Keywords: Speech Acts, Illocution, Online Learning

$\begin{array}{ll}\text { History: } & \\ \text { Received } & : \text { 24 January } 2021 \\ \text { Revised } & : 02 \text { March } 2021 \\ \text { Accepted } & : 30 \text { March } 2021 \\ \text { Published } & : 25 \text { April } 2021\end{array}$

Publisher: Undiksha Press

Licensed: This work is licensed under

a Creative Commons Attribution 3.0 License

(c) (i) (2)

\section{Introduction}

Corona Virus Disease (Covid-19) has hit 215 countries in the world since mid-March 2020, creating challenges in implementing educational activities, including in Indonesia. In response to this, the government has implemented several measures, including prohibiting people from crowding around, enforcing social distancing, maintaining physical distancing, obligatory facemasks, and frequent handwashing (Sadikin \& Hamidah, 2020; Wijayanengtias \& Claretta, 2020). The Covid-19 pandemic has drastically changed the learning model both globally and on a local scale. Therefore, the Office of Youth and Sports Education in the Special Region of Yogyakarta decided to execute an online learning policy as a follow-up to the Circular of the Minister of Education and Culture of the Republic of Indonesia Number 4 of 2020 concerning the Implementation of Education Policies in the Emergency of the Spread of Corona Virus Disease (Covid-19). Through this decree, the government prohibited schools from conducting face-to-face learning and ordered learning from home by implementing online / distance learning (Handayanto \& Herlawati, 2020; Syauqi et al., 2020).

Online learning uses internet networks with accessibility, connectivity, flexibility, and the ability to generate various learning interactions (McGrew et al., 2018; Syarifudin, 2020). To run successful online learning requires the support of mobile devices such as smartphones, tablets, and laptops that can be used to access information anywhere and anytime (Gikas \& Grant, 2013). There are many options of media that educators may use to 
support the implementation of online classroom learning, such as virtual classes using Google Classroom, Edmodo, and Schoology services (Enriquez, 2014; Iftakhar, 2016; Sicat, 2015) and instant messaging applications such as WhatsApp (Daheri et al., 2020; So, 2016).

In everyday life, humans use language for various activities. Pragmatically, language is one of the actions commonly referred to as speech acts (Ekawati, 2017). Communication between teachers and students in learning interactions can be done either face-to-face or online. Learning activities carried out by teachers cannot be separated from language activities. Likewise, the speech acts performed by teachers in online learning cannot be separated from their speech conveyed through various media. Faelani \& Setyowati (2018) suggest that the speech acts carried out by teachers aim to attract attention, influence, and convince students to do what they are expected to do. The teacher's speech acts in teaching are fundamental in empowering students by prioritizing motivation for students. The enthusiasm of students to learn will grow as a result of the speech delivered by the teacher.

In both face-to-face and online learning, teachers certainly use good speech acts in delivering material to students. Teachers also have to be able to understand the character of students. This will make it easier for students to understand the material presented by the teacher. The delivery of learning material by the teacher is prone to causing misunderstandings to students. Therefore, it is necessary to understand and analyze the meaning behind the speech conveyed by the teacher in the learning process. With various speech acts, teachers and students communicate face-to-face in learning. The communication between the teacher and students is expected to convey ideas to be understood, accepted, and followed by other people as interlocutors (Susmita, 2019).

Studies that examine speech acts in learning have been widely conducted, one of which was done by Asrianti (2019b), which reveals that teachers represent power through various forms, strategies, and functions. The study was conducted to investigate teacher power's form, strategy, and function in learning discourse in junior secondary schools. Ekawati conducted another similar study to show that angry speech acts can be done with the indirect sentence mode (interrogative sentences and news) and the implicit meaning and focus on the $3^{\text {rd }}$ person (O3). Anger addressed to the $3^{\text {rd }}$ person is manifested as pseudo politeness - or the sustained politeness considering the anger is not unleashed to the $2^{\text {nd }}$ person $(\mathrm{O} 2)$. Pseudo politeness also functions to maintain social relations between friends, family, and community. Angry speech acts can be done in an indirect sentence mode, but with an explicit meaning and focus on the O2. Angry speech acts can be carried out in direct sentence mode with an explicit meaning with or without the $\mathrm{O} 2$ 's response.

A study on speech acts in learning has also been conducted by Hasanah \& Widodo (2017) show that all the functions of assertive, directive, commissive, expressive, and declarative illocutionary acts were found during classroom learning. The illocutionary act that dominated the speech of the teacher and students was the asking directive, while the least used illocutionary act was commissive. The dominant form of verbal speech was direct speech. Tarmini (2016) found a form of representation of power in lecturers' speech acts, including representation of power in the directive, assertive, and expressive speech acts. Faelani \& Setyowati (2018) revealed the types of Searle's speech acts in the learning process, including illocution and perlocution. The recorded speech act functions were assertive, expressive, commissive, and declarative.

Yanto (2014) elicited power in a teacher's speech acts in Indonesian language learning. This study shows that the teacher demonstrated power in the directive, assertive, and expressive speech acts. Puspitasari (2020) shows five forms and functions of the teacher's speech acts in learning. The speech acts include perlocutionary, representative, directive, commissive, and expressive speech acts, while the perlocution speech acts include perlocution of praise, statements and promises. The representative speech acts found were 
only representative statements while the expressive speech acts identified include praising, criticizing and apologizing. Further, the directive speech acts found include the directive of orders, requests, advice, and prohibitions. The commissive speech acts found were commissive promises, threats and offers.

Regarding the use of language, the diversity of teacher speech acts in learning, especially in online learning, is an interesting phenomenon to study. Even though the teacher implements online learning, it is believed that she/he performs various speech acts conveyed in written messages. Such diversity includes assertive, directive, commissive, expressive, and declarative speech acts. Hence, this study aims to describe the forms of illocutionary acts and representations of an Indonesian teacher's power strategies in online learning interactions through WhatsApp and Google Classroom.

\section{Materials and Methods}

A qualitative descriptive study describes the illocutionary acts used by a teacher in online learning interactions within an Indonesian language subject during the Covid-19 pandemic. This study involves an Indonesian language teacher and students, totaling 36 students. The data was gathered from written conversational speeches conveyed by the teacher and students through WhatsApp and Google Classroom during online learning. Therefore, the teacher and students' written interaction is the primary source of the data and will be further discussed in the next section.

The data was collected through the use of the message note technique, aiming to record all the messages sent by the teacher and students through WhatsApp and Google Classroom during online learning. As a result, the data collected is in the form of speech acts in written discourse. Data analysis was conducted using the Miles and Huberman model, including data collection, data reduction (data presentation), drawing temporary conclusion and verification, and conclusion and recommendation.

\section{Results and Discussion}

The teacher performed various speech acts in online learning interactions via WhatsApp and Google Classroom. Based on the data analysis, the types of illocutionary acts found are assertive, directive, commissive, and expressive illocutionary acts. Assertive illocutionary acts consist of stating information, expressing opinions, conclusions, and affirming. The directive illocutionary act consists of ordering and asking, which branch out to some variations, including illocutionary directive acts asking for a response and asking for an answer. Finally, commissive illocutionary acts consist of promising and refusing. Meanwhile, expressive illocutionary acts consist of saying thank you, congratulating, complaining, apologizing, saying condolences, and expressive illocutionary acts praising. The details of the findings are described in the following passage below.

\section{Assertive Illocutionary Act in Online Learning interactions}

Assertive is a type of speech act that implies whether the speaker believes to be the case. Instances of this speech act type include stating a fact, reporting, expressing opinions, making conclusions, affirming, and proposing. In addition, several assertive illocutionary acts were found in this study: assertive illocutionary acts of stating information, expressing opinions, making conclusions, and assertive illocutionary acts of asserting.

An example of assertive illocutionary acts states information in online learning interactions through the Google Classroom (GCR) media sent by the teacher on July 13, 2020, namely "Nah... We will learn online through this media, and sometimes we will open the class first by greeting you via google meet. 
The context of the speech delivered by the Indonesian language teacher through the media was delivered at the beginning of the odd semester in the 2020/2021 school year as notification or information to students about the learning system to be carried out. To emphasize the importance of this information, the teacher wrote it in capital letters so that students would pay special attention to the part of the information conveyed in writing through the GCR.

Data on assertive speech act "expressing opinions" is also found in Indonesian online learning interactions. The example of the assertive illocutionary act "expressing opinions" in online learning interactions through the relevant WAG is "What if you use a mobile, mas/Pake HP pie mas."

The context of the speech is in the form of expressing opinions conveyed by the teacher when the students have not entered the PAS examination system through the Gschool application. For example, one of the students who had not logged in argued that his laptop had an error, and then the teacher expressed his opinion in a written speech, "Pake HP pie mas," which means "What if you use a mobile, mas?". The speech stated by the teacher was in Javanese because the communication between the teacher and students was intimate and gave an impression of being relaxed so that students were not nervous about taking the exam even though it was too late.

The data on assertive speech act "making conclusions" is found in the interaction of Indonesian language online learning. The example of the assertive illocutionary act "concluding" in online learning interactions is "Jadi/So."

The context of the speech conveyed by the Indonesian language teacher in the online learning media is to make conclusions on the information previously described, where students were asked to make the best use of their time in lecture text PH activities through the quizizz application. The teacher made this conclusion because the time provided for each question was only 45 seconds, with a total of 40 questions. The word "jadi" in the speech is also written in bold type to emphasize the importance of the information conveyed.

Data on "affirming" assertive speech acts is also found in Indonesian online learning interactions. The example of assertive illocutionary " act "affirming in online learning interactions is "Nah, for today's learning activities, ....

The context of the speech delivered by the Indonesian language teacher in the online learning media was to confirm the information delivered that day, which was related to the material at the previous meeting, namely the practice of PTS questions. It was customary that prior PTS, the teacher would give assignments in the form of practice questions. At the next meeting, the teacher would give the answer key to the PTS question exercises to find out what score they obtained (how well they did the exam). In addition, the teacher also delivered a summary of the PTS material to students for learning materials. The affirmation of the information is marked by the use of the word "Nah..".

\section{Directive Illocutionary Act in Online Learning Interactions}

A directive is a type of speech act used by speakers to tell other people to do something. Directive speech can be in the form of orders (ordering), asking, suggesting, inviting, pleading, suggesting, demanding, and giving advice. The study found the illocutionary act of the directive commands/orders, and the illocutionary act of the directive asks.

The example of directive illocutionary act "asking/ordering" within the interaction of the online learning is "silakan berdoa terlebih dahulu, lalu mengisi link presensi yang diberikan...; silakan kalian membaca dan mempelajari materi yang diberikan di GCR/please pray first, and then take your attendance in the link that I have given you; please read and study the material that I gave you in GCR." 
The context of the speech conveyed by the Indonesian language teacher in the online learning media is instructing or commanding students subtly by using the word choice "silakan/please." For example, students are asked to pray to start learning and then fill in the presence link as evidence of their presence in the teaching and learning activities. In addition, students are instructed to read and study the material provided by the teacher. The use of the word "silakan/please" is a form of subtle command so that it gives the impression to students that the teacher is not authoritarian.

The data on the speech act of directive "requesting" is also found in Indonesian online learning interactions. The example of a directive speech act "requesting" (1) in online learning interaction is "Kapan ikutnya? Nhen did you take it?"

The context of the speech conveyed by the Indonesian language teacher in the online learning media is requesting students to answer the teacher's questions by giving question sentences related to the follow-up assessment activities that must be taken by students who have not participated in the main $\mathrm{PH}$. The question arose when there was a reaction from a student who said that she/he had attended PH with the answer "Sudah, Bu/Done, Mom." To confirm his/her response, the teacher asked the question, "Kapan ikutnya? / When did you take it?"

The example of directive speech act "requesting" (2) in online learning interaction is "Spesial utk mas M Rafi, Akun di GCR namanya Cahaya Udin. Tolong akun diganti sesuai nama aslinya, ini juga peringatan untuk peserta didik yang lain. Mohon namanya disesuaikan karena bisa jadi bapak ibu guru tidak tahu siapa pemilik akun itu dan akan menganggapnya tidak mengumpulkan tugas. Special for Mas M Rafi, your account name in GCR is Cahaya Udin. This warning also applies to the others. Please rename your account name according to your real name because we (teachers) may not acknowledge the account owners and will assume that the unrecognized account owners did not submit assignments.

The context of the speech delivered by the Indonesian language teacher in the online learning media is requesting a response from a student named M Rafi to change his GCR account name because it does not match his real name. The teacher employed the word choice "spesial/special" since she wanted M Rafi to respond to the information posted immediately.

\section{Commissive Illocutionary Act in Online Learning Interactions}

Commissive is a type of speech act that speakers understand to tie themselves to actions in the future. This speech act can be a promise, rejection, pledge, promise, offer, commitment declaration, and vows. An example of a commissive speech act "promising" in online learning interactions is "Hari ini saya janji akan menjelaskan melalui Google Meet mulai pukul 08.45 - 09.15 WIB untuk menjelaskan kembali materi teks eksplanansi agar kalian lebih paham" / Today through Google Meet I promise that I will give you another explanation on the explanation text, starting at 08.45 until $09.15 \mathrm{WIB}$, so that you will understand it better.

The context of the speech conveyed by the Indonesian language teacher in online learning media demonstrates the ability to re-explain the material that has been given through Google meet. Furthermore, because the explanation text material delivered the previous week was only in the PowerPoint slide, the teacher promised to re-explain the material through virtual face-to-face, aiming to understand better the material taught.

Data on commissive speech act "rejecting" is also found in the online learning interaction in an Indonesian language subject. An example of commissive speech act "refusing" in online learning interaction is "Pekerjaan saya kembalikan, silakan diperbaiki ya dan tolong diupload hari ini") "I will return your work and please revise and reupload it today". 
The context of the speech delivered by the Indonesian language teacher in the online learning media is "refusing" by returning the assignment that the student had collected because the answers did not match the instructions. As a result, she was asked to revise and re-upload her work that day. The rejection given by the teacher was also conveyed using soft words accompanied by instructions with word choices "silakan and tolong/please." This speech act was deliberately chosen to avoid hurting her feelings as the teacher returned her work.

\section{Expressive Illocutionary Acts in Online Learning Interactions}

Expressive is a type of speech act that expresses something that the speaker feels. The speech act reflects psychological statements and can be statements of joy, criticism, hatred, pleasure, misery, gratitude, congratulations, apology, complaint, criticism, praise, and condolences. The study revealed several expressive illocutionary acts, including saying thank you, congratulating, complaining, apologizing, saying condolences, and praising.

An example of the expressive illocutionary act "saying thank you" found in the online learning interaction is "Saya mengucapkan terima kasih/I would like to thank." Expressive speech acts were conveyed in the context of the last meeting so that the teacher expressed appreciation to students who had completed the assignments by saying thank you.

An example of expressive illocutionary act "congratulating" is "Saya juga mengucapkan selamat atas keberhasilan kalian... / I also congratulate you on your success...". The context of the speech conveyed by the teacher is to appreciate students who have completed semester 1 online learning well. An example of expressive illocutionary act "complaining" is shown in the teacher's statement, which is "Manusia tidak ada yang sempurna, masih saja ada peserta didik yang belum maksimal dalam mengikuti dan menyelesaikan tugas... / Humans are not perfect, and there are still students who have not maximally tended and completed the assignments...."

The teacher's context was conveyed because the efforts made to motivate the students during the online learning were not entirely successful since there were still students who had not been able to complete the assignments until the end of the teaching and learning activities. Therefore, with this speech, it was hoped that the students could immediately complete the assignments.

An example of an expressive illocutionary act "expressing condolences" appears in the teacher's statement, which is "Ikut berduka cita Mas Ardy atas wafatnya Nenek tercinta, semoga almarhumah husnul khotimah / Mas Ardy, my deep condolences to the death of your beloved grandma, I hope she passed away in good condition." The context of the speech act emerged due to the presence of an obituary - some student's grandmother just passed away. To express her feeling of grief, the teacher conveyed a written message addressed to the affected student.

\section{Representation of Teacher's Power Strategies in Indonesian Language Online Learning Interactions}

The representation of power strategies used by the teacher in online learning through WhatsApp and Google Classroom includes speech control, threats, and anger/pretending to be angry with insinuation.

\section{Speech control}

Speech control is carried out by a teacher, indicated by many messages in classroom activities in segmental and suprasegmental quality. Segmentally, a teacher, uses many words that make students feel dominated by the teacher. For example, a command sentence is accompanied by the words "harus and segera/have to and immediately." Suprasegmentally, a 
teacher, utilizes messages in the form of prohibitions and affirmations in bold print conveyed in written messages sent during online learning through the WAG and GC applications.

The data quotations show that students obeyed the teacher's orders that were conveyed using the speech "segera and harus/immediately and have to." The use of these words made students unable to refuse the teacher's orders with a speech other than "iya/yes." Thus, the spoken dialogue in the message can be controlled by the teacher.

\section{Use of threats}

Using threats is a speech strategy in representing power in online learning classroom discourse. The teacher used threats as a form of classroom management that aim to control the completeness of the collection of assignments given to students. The quotation of the speech used by the teacher in online learning through WAG was delivered using a threat strategy so that students who have not submitted their assignments can be inspired and motivated to complete them. Using threats to report their behaviors to their parents is indicated by using the "jika/if" conjunction as a precondition.

\section{The use of anger / pretending to be angry with insinuation}

Being angry or pretending to be angry with insinuation is a strategy used by teachers to control the online learning class. This was meant to embolden the teacher's power and that she would be trusted, obeyed, and followed.

The quotation of speech used by the teacher in online learning through WAG was conveyed with an angry strategy through insinuation using motivational sentences. This was meant to motivate the students who have not entirely submitted the assignments. The teacher no longer knew how to make the students complete their assignments. The choice of the sentence "Sekali lagi, berjuanglah maka saya pun akan memperjuangkan kalian" / "Once again, keep struggling and then I will defend/help you" is an expression of the teacher's anger by insinuating that the teacher will not incentivize the final grades of the students who are unwilling to struggle to complete the incomplete assignments.

\section{Discussion}

The speech act is the intention of utterance as an action that is stated through a speech. A speech act is the smallest unit of a person's speaking activity (conversation or discourse) in social interactions (Munawir, 2018; Yanto et al., 2013). Another opinion suggests that a speech act is an utterance that contains intention, purpose, or illocutionary power and impacts the interlocutor or listener. Speech acts can be in the form of sounds, words, phrases, sentences, or discourses that have a specific purpose and impact on the listener (Faelani \& Setyowati, 2018; Saifudin, 2019).

In the same source, Austin suggested dividing speech acts into three, including locus, illocution, and perlocution. All these three occur at the time as a speech is spoken. The locus act is the act of saying something. Austin states that locus is simply telling something, conveying information, talking, asking, and so on. The speech act of illocution is doing something based on what is being said (Munawir, 2018; Saifudin, 2019). Illocution is what is achieved by communicating the intention to achieve something. The perlocution is an action or state of mind that is brought about by or as a consequence of saying something. According to Austin, the action of perlocution is what we produce or achieve by saying something, such as convincing, cajoling, blocking, saying, surprising or misleading. Perlocution act thus must be understood as a causal relationship between two events caused by the production of speech by the speaker. Among the three types of speech act, the most dominant one within the study of pragmatics is the act of illocution. The essence of speech acts, and at the same 
time, a study of performative speech, as stated by Austin, is the illocution contained in a speech (Puspitasari, 2020; Saifudin, 2019).

Furthermore, Hasanah \& Widodo (2017); Saifudin (2019) classified illocutionary acts into five categories: assertive, directive, commissive, expressive, and declarative. The assertive speech act is speech that binds the speaker to the proposition's truth-for example, stating, suggesting, boasting, complaining, and claiming. A directive is a speech act intended for the speech partner to act according to the speech. For example, ordering, ordering, begging, advising, and recommending. Commissive requires the speaker to commit to doing something in the future. For example, promising, swearing, rejecting, threatening, and guaranteeing. The expressive speech act is an expression of attitudes and feelings about a situation or reaction to people's attitudes and actions. For example, congratulating, being grateful, regretting, apologizing, and welcoming. Finally, the declarative speech act is an illocution that causes a change or conformity between a proposition and reality-for example, baptizing, firing, naming, and punishing.

Power may take place anywhere, including in-class (Asrianti, 2019; Tarmini, 2016). According to Jumadi (2005), the use of power cannot be separated from the field of education, especially schooling. School is one of the social institutions where the culture is not equal. Learning interactions involving teachers and students represent inequality between factors in school institutions (Ismail, 2018; Triana \& Zamzani, 2019). Teacher's power in classroom discourse is used to control students' behavior (Asrianti, 2019). Online learning classrooms are thought to be a net of power that disseminates discourse on an ongoing basis. The components involved are teachers and students through the use of remote classroom discourse.

In learning, teachers have more power and control over students because of the authority they have. As a result, teachers can carry out social practices that illustrate power over students. Teachers carry out authority as a regulator of class discipline and as a material provider in the learning. As a result, teachers become very knowledgeable during the learning process (Triana \& Zamzani, 2019).

In representing his/her power, a teacher uses several strategies to oversee all activities carried out by students in learning. The speech control strategy is one of the teacher's strategies used in distance learning or online classroom discourse. Power through speech acts that occurs during the learning process can occur through the teacher's speech strategies to students (Asrianti, 2019). Representation of power strategies includes: (1) speech control, (2) using threats, (3) being angry / pretending to be angry.

\section{Conclusion}

Two conclusions may be drawn based on the study results about teacher's illocutionary acts in online learning interaction. First, the forms of the teacher's illocutionary acts in Indonesian online learning interactions include assertive, directive, commissive, and expressive. No declarative illocutionary acts were found. The assertive illocutionary acts found include stating information, expressing opinions, making conclusions, and affirming. The illocutionary directive acts include ordering and asking. The commissive illocutionary acts include promising, while the commissive illocutionary acts consist of rejecting. The expressive illocutionary acts include saying thank you, congratulating, complaining, apologizing, and saying condolences. The expressive illocutionary acts include praising. Second, the representation of power strategies in teacher's speech acts during the Indonesian language online learning interactions includes speech control, using threats, and being angry/pretending to be angry with insinuation. 


\section{References}

Asrianti, A. (2019). Representasi kekuasaan dalam wacana kelas di Sekolah Menengah Pertama. RETORIKA: Jurnal Bahasa, Sastra, Dan Pengajarannya, 12(1), 14-24. https://doi.org/10.26858/retorika.v12i1.7384.

Daheri, M., Juliana, Deriwanto, \& Amda, A. D. (2020). Efektifitas WhatsApp sebagai Media Belajar Daring. Basicedu, 4(4), 775-783. https://doi.org/10.31004/basicedu.v4i4.445.

Ekawati, M. (2017). Kesantunan Semu pada Tindak Tutur Ekspresif Marah dalam Bahasa Indonesia. Adabiyyāt: Jurnal Bahasa Dan Sastra, 1(1), 1-22. https://doi.org/10.14421/ajbs.2017.01101.

Enriquez, M. A. S. (2014). Students' Perceptions on the Effectiveness of the Use of Edmodo as a Supplementary Tool for Learning. DLSU Research Congress. https://doi.org/10.1017/CBO9781107415324.004.

Faelani, N., \& Setyowati, E. (2018). Tindak Tutur dalam Pembelajaran Bahasa Indonesia Peserta didik Kelas VII SMP Negeri 2 Pacitan Tahun Pelajaran 2016/2017. Prakerta (Jurnal Penelitian Bahasa, Sastra Dan Pengajaran Bahasa Indonesia), 1(1), 54-61. https://ejournal.stkippacitan.ac.id/index.php/prakerta/article/view/109.

Gikas, J., \& Grant, M. M. (2013). Mobile computing devices in higher education: Student perspectives on learning with cellphones, smartphones \& social media. Internet and Higher Education, 19, 18-26. https://doi.org/10.1016/j.iheduc.2013.06.002.

Handayanto, R. T., \& Herlawati, H. (2020). Efektifitas Pembatasan Sosial Berskala Besar (PSBB) di Kota Bekasi Dalam Mengatasi COVID-19 dengan Model SusceptibleInfected-Recovered (SIR). Jurnal Kajian Ilmiah, 20(2), 119-124. https://doi.org/10.31599/jki.v20i2.119.

Hasanah, S. U., \& Widodo, M. (2017). Tindak Tutur Guru Dan Siswa SMP pada Pembelajaran Bahasa Indonesia Dan Implikasinya. J-SIMBOL (Bahasa Dan Sastra Indonesia), 5(1). https://core.ac.uk/download/pdf/293165307.pdf.

Iftakhar, S. (2016). Google classroom: what works and how? Journal of Education and Social Sciences, 3(2), 12-18. http://jesoc.com/wpcontent/uploads/2016/03/KC3_35.pdf.

Ismail, A. (2018). Pilihan Kosakata Nilai Eksperiensial Kosakata Kekuasaan Guru Perempuan Bugis dalam Pembelajaran Bahasa Indonesia. Retorika: Jurnal Bahasa, Sastra, Dan Pengajarannya, 11(2), 119-128. https://doi.org/10.26858/retorika.v11i2.6367.

McGrew, S., Breakstone, J., Ortega, T., Smith, M., \& Wineburg, S. (2018). Can students evaluate online sources? Learning from assessments of civic online reasoning. Theory \& Research in Social Education, 46(2), 165-193. https://doi.org/10.1080/00933104.2017.1416320.

Munawir, M. (2018). Tindak Tutur Guru dalam Pembelajaran Bahasa Indonesia Di Kelas XII SMK Negeri 1 Narmada. Jurnal Ilmiah Telaah, 3(1), 25-32. https://doi.org/10.31764/telaah.v3i1.303.

Puspitasari, D. (2020). Tindak Tutur Guru Dalam Pembelajaran Bahasa Indonesia Pada Kelas VII MTsN 4 Palu. Jurnal Bahasa Dan Sastra, 5(3). https://core.ac.uk/download/pdf/289713905.pdf.

Sadikin, A., \& Hamidah, A. (2020). Pembelajaran Daring di Tengah Wabah Covid19:(Online Learning in the Middle of the Covid-19 Pandemic). Biodik, 6(2), 214-224. https://doi.org/10.22437/bio.v6i2.9759.

Saifudin, A. (2019). Teori Tindak Tutur dalam Studi Linguistik Pragmatik. Lite: Jurnal 
Bahasa, Sastra, Dan Budaya, 15(1), 1-16. https://doi.org/10.33633/lite.v15i1.2382.

Sicat, A. (2015). Enhancing College Students' Proficiency in Business Writing Via Schoology. International Journal of Education and Research, 3(1), 159-178. http://www.ijern.com/journal/2015/January-2015/14.pdf.

So, S. (2016). Mobile instant messaging support for teaching and learning in higher. The Internet Higher Education, 31, 32-42. https://doi.org/10.1016/j.iheduc.2016.06.001.

Susmita, N. (2019). Tindak Tutur Guru dan Siswa dalam Pembelajaran Bahasa Indonesia. JPGI (Jurnal Penelitian Guru Indonesia), 4(1), 25-30. https://doi.org/10.29210/02353jpgi0005.

Syarifudin, A. S. (2020). Implementasi Pembelajaran Daring untuk Meningkatkan Mutu Pendidikan Sebagai Dampak Diterapkannya Social Distancing. Jurnal Pendidikan Bahasa Dan Sastra Indonesia Metalingua, 5(1), 31-34. https://doi.org/10.21107/metalingua.v5i1.7072.

Syauqi, K., Munadi, S., \& Triyono, M. B. (2020). Students' perceptions toward vocational education on online learning during the COVID-19 pandemic. International Journal of Evaluation and Research in Education, 9(4), 881-886. https://doi.org/10.11591/ijere.v9i4.20766.

Tarmini, w. (2016). Representasi Kekuasaan pada Tindak Tutur Dosen di Lingkungan FKIP Universitas Lampung: Sebuah Kajian Pragmatik. Prosiding Konferensi Internasional IKADBUDI VI. http://repository.lppm.unila.ac.id/id/eprint/3057.

Triana, P. M., \& Zamzani, Z. (2019). Representasi Kekuasaan pada Bentuk Gramatikal Tindak Tutur Guru dalam Pembelajaran Bahasa Indonesia. Lensa: Kajian Kebahasaan, Kesusastraan, Dan Budaya, 9(1), 77-89. https://doi.org/10.26714/lensa.9.1.2019.77-89.

Wijayanengtias, M., \& Claretta, D. (2020). Student Perceptions of Online Learning During the Covid-19 Pandemic. Kanal: Jurnal Ilmu Komunikasi, 9(1), 16-21. https://doi.org/10.21070/kanal.v9i1.685.

Yanto, J. A., Rusminto, N. E., \& Tarmini, W. (2013). Representasi Kekuasaan Pada Tindak Tutur Guru dalam Pembelajaran Bahasa Indonesia. J-SIMBOL (Bahasa Dan Sastra Indonesia), 1(2). https://core.ac.uk/download/pdf/293165348.pdf. 